\title{
UJI TANAMAN TALAS (Colocasia esculenta) SEBAGAI AGEN FITOREMEDIASI AIR SUNGAI CIKAPUNDUNG
}

\author{
Testing of Taro Plant (Colocasia esculenta) as Phytoremediation \\ Agent Water in Cikapundung River
}

\author{
Kusno Wibowo dan Wage Komarawidjaja \\ Pusat Teknologi Lingkungan \\ Badan Pengkajian dan Penerapan Teknologi , \\ Jalan M.H. Thamrin No. 8 Jakarta 10340 \\ Email :wage.komarawidjaja@bppt.go.id
}

Diterima : 14 Juni 2012; Koreksi : 20 Juni 2012; Disetujui : 3 Juli 2012

\begin{abstract}
Pollution of rivers due to the accumulation of domestic and industrial wasteis aserious challenge to the survival ofaquatic biota. Domestic waste/ household is often thrown into the water can interfere waters ecosystems. So far, many efforts have been done such as installation integrated waste treatment, but these efforts are not yet fulfill the requirement due to low awareness and lack of oversight agencies. One of the efforts to reduce domestic wasteis by making use of plant biology irrigation with Colocasia esculenta. Study ofutilization of aquatic plants for domestic wastewater treatment systems biology irrigation was conducted to determine the efficiency of nutrient uptake by C.esculenta. The research method was applied by growing C.esculenta in an experimental container -carrying raceways domestic wastewater system with subsurface flow (SSF). The results showed that physical C.Esculenta may grow well on substrates containing water Cikapundung river compared to C.Esculentagrown ona substrateis added waterwells. This is shown by the differences in growth and weight of the plants. The results of the Laboratory analysis of organic carbon (C-organic), nitrogen (N-kejdahl) and phosphate (P) on the taro plant (the leaves and roots) showed an increase nutrient in plant tissues which is directly proportional to the growth of taro plants (taro plant height and weight), as shown by a concentration of $2000 \mathrm{mg} C$ sequestration and $\mathrm{N100} \mathrm{mg}$ for 63 days.
\end{abstract}

Keywords: Colocasia esculenta, domestic waste, phytoremediation.

\begin{abstract}
Abstrak
Pencemaran sungai akibat akumulasi limbah domestik dan industri merupakan tantangan yang serius bagi kelestarian hidup biota perairan. Limbah domestik/rumah tangga yang sering dibuang ke perairan dapat mengganggu ekosistem yang ada di perairan tersebut. Sejauh ini berbagai upaya sudah mulai dilakukan industri dengan pembuatan instalasi limbah terpadu, namun upaya tersebut masih belum maksimal karena rendahnya kesadaran masyarakat dan lemahnya pengawasan dari instansi terkait. Salah satu upaya untuk mengurangi limbah domestik adalah dengan membuat biology irigation dengan memanfaatkan tanaman talas Colocasiaesculenta. Studi pemanfaatan tanaman air untuk pengolahan air limbah domestik dalam sistem biology irigation ini dilakukanuntuk mengetahui efisiensi penyerapan unsur hara oleh C. esculenta. Metode penelitian yang diterapkan adalah menumbuhkan $\mathrm{C}$. esculenta dalam suatu wadah percobaan race ways yang dialiri air limbah domestic dengan sistem subsurface flow (SSF). Hasilpenelitian menunjukkanbahwa secara fisik C.Esculenta dapat tumbuh lebih baik pada substrat yang mengandung air sungai Cikapundung dibandingkan dengan C.Esculenta yang ditumbuhkan pada substrat yang ditambahkan air sumur. Hal tersebut ditunjukkan oleh perbedaan pertumbuhan panjang dan berat tanaman tersebut. Hasil analisis parameter karbon organik (C-organik), nitrogen ( $\mathrm{N}$-kejdahl) dan fosfat $(\mathrm{P})$ pada jaringan tanaman talas (bagian daun dan akar) menunjukkan adanya peningkatan konsentrasi bahan organik dalam jaringan tanaman tersebut yang berbanding lurus dengan pertumbuhan tanaman talas (tinggi dan berat tanaman talas), sebagaimana ditunjukkan oleh konsentrasi penyerapan C sebesar 2000 $\mathrm{mg}$ dan $\mathrm{N} 100 \mathrm{mg}$ selama 63 hari.
\end{abstract}

Kata kunci : Colocasia esculenta, limbah domestik, fitoremediasi. 


\section{PENDAHULUAN}

Peningkatan jumlah penduduk Indonesia yang tinggi berkorelasi pada peningkatan produksi limbah rumah tangga yang dihasilkan. Limbah rumah tangga yang merupakan bahan sisa yang sudah tidak dipergunakan menjadi masalah yang sulit diselesaikan berkaitan dengan kurangnya kesadaran masyarakat akan bahaya limbah terhadap kelestarian lingkungan. Limbah rumah tangga sering dibuang ke perairan dan sungai-sungai sehingga dapat menggangu eksosistem yang ada di perairan tersebut.

Limbah rumah tangga umumnya berupa bahan organik dan an-organik atau bahan bahan lain yang berbahaya bagi lingkungan. Bila bahan-bahan tersebut terakumulasi dalam suatu perairan, maka keberadaan bahan tersubut dapat menyebabkan penyuburan (eutrofikasi) perairan sehingga terjadi blooming alga tertentu. Kejadian blooming ini tentu akan mengangu ekosistem perairan tersbeut karena kesetimbangan oksigen terlarut menjadi terganggu, dan timbul senyawa beracun seperti $\mathrm{H} 2 \mathrm{~S}$ dan metana dari pembusukan biomasa alga paska periode blooming.

Masalah lain yang ditimbulkan oleh limbah rumah tangga adalah pencemaran air sehingga kualitas air perairan tersebut menjadi menurun. Selain itu limbah rumah tangga juga menyebabkan penurunan estetika lingkungan perairan akibat bau dan warna air yang tidak sedap dipandang mata.

Berbagai metode untuk mengurangi dampak limbah rumah tangga tersebut telah banyak dilakukan namun masih terkendala seperti mahalnya peralatan dan instalasi pengolah limbah. Upaya menetralisis limbah dengan mengunakan bahan kimia seperti $\mathrm{Al} 2(\mathrm{SO} 4) 3$, $\mathrm{Fe} 2(\mathrm{SO} 4) 3$, Klorin, dan bahan yang lain juga dihantui oleh dampak buruk dari residu bahan kimia yang digunakan. Oleh sebab itu perlu dikembangkan metode untuk menanggulangi limbah rumah tangga yang ramah lingkungan serta murah dan mudah diterapkan di masyarakat

Salah satu upaya untuk mengurangi limbah domestik yang ramah lingkungan adalah dengan membuat biology irigation dengan memanfaatkan tanaman talas Colocasiaesculenta. Biology irigation adalah salah satu sistem pengenceran serta penyerapan bahan toksik yang terlarut dalam air secara biologi (mengunakan tanaman air) dengan melalukan air limbah sebagai irigasi. Pengaliran air limbah dilakukan dengan sistem subsurface flow (SSF). Dalam sistem ini aliran air limbah dilalukan dibawah rooting media (kerikil). Karena permukaan air tetap terjaga di bawah ujung kerikil media, maka kemungkinan timbulnya bau, bersarangnya serangga vector dan sampah lainnya bisa diminimalkan. (Yang et al., 2001). Tanaman talas Colocasiaesculenta digunakan sebagai agent penyerap polutan karena tanaman ini memiliki laju pertumbuhan yang tinggi, bersifat kosmopolit sehingga dapat dibiakkan disemua kondisi media serta terbukti handal mampu menyerap polutan di lingkungannya. Adapun tujuan penelitian ini untuk mengetahui kemampuan tanaman talas Colocasiaesculenta dalam memanfaatkan nutrien terlarut (nutrient uptake) dalam air sungai Cikapundung.

\section{BAHAN DAN METODE}

\subsection{Waktu, Tempat dan Wadah}

Kegiatan kajian ini dilaksanakan dari tanggal 5 Juli sampai dengan tanggal 6 September 2012, selama kurang lebih 63 hari, di bantaran Sungai Cikapundung, tepatnya di bawah lintasan jalan layang Tol Pasopati. Wadah kajian adalah berupa 2 kolam beton, yang masing-masing berukuran $10 \times 1 \times 1$ meter kubik, dengan desain seperti ada pada Gambar 1 dan Gambar 2.

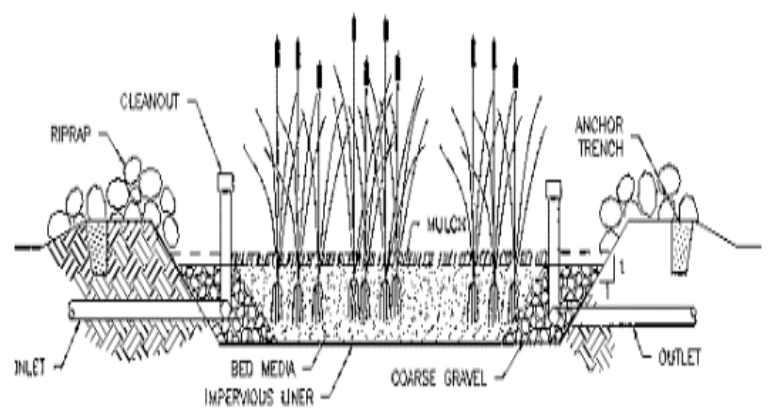

Gambar 1. Ilustrasi Adopsi Kolam Fitoremediasi

Bak-1 dan -2 ditanami dengan tanaman yang sama, yakni talas/bolang (Colocasiaesculenta) dan tanaman lainnya. Bak-1 dialiri dengan air Sungai Cikapundung (kaya nutrien) yang sebelumnya dipompa ke penampung air 500 liter, selanjutnya disebut Kolam AS, Sedangkan Bak-2 dialiri dengan air sumur/tanah (yang miskin nutrient) yang sebelumnya juga telah ditampung di penampung air 500 liter, selanjutnya disebut sebagai Kolam AT.

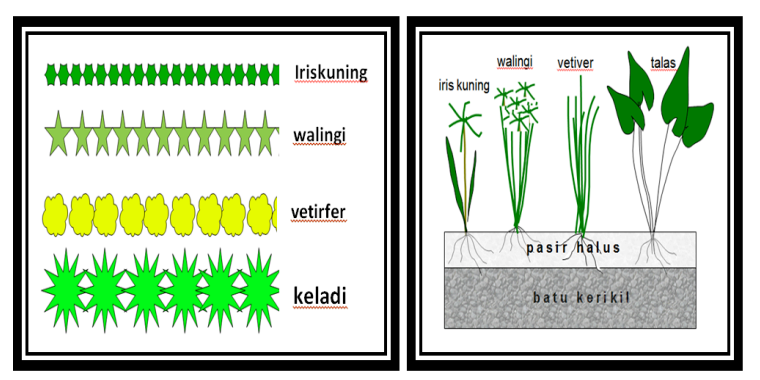

Gambar 2. Penempatan masing-masing tanaman pada wadah/media kajian dilihat dari atas( kiri) \& samping (kanan) 


\subsection{Pengambilan Contoh.}

Selama kajian, pengambilan contoh pada Kolam AS dan Kolam AT dilakukan 3 minggu sekali yakni Tanggal 6 Juli (t-0); 26 Juli (t-1), 16 Agustus (t-2) dan 6 September 2012 (t4). Data-data tersebut meliputi data fisik yang terdiri dari panjang total, berat kering total (akar, batang dan daun), dan data kimia yang meliputi total carbon ( Ctotal ), total nitrogen (Ntotal) danfosfor ( $\mathrm{P}$ ). Selanjutnya data sampel dari Kolam AS akan disebut sebagai sampel AS atau data AS, dan data sampel dari Kolam AT akan disebut sebagai sampel AT dan data AT.

Data fisik diperoleh dari hasil pengukuran dilapangandandilaboratoriumBTL, sedangkandata kimiadiperolehdarihasilanalisadilaboratoriumBTL.

\section{HASIL DAN PEMBAHASAN}

\subsection{Karakterisasi Air Kolam Kajian}

Data hasil pemeriksaan beberapa parameter kualitas air yang digunakan pada Kolam AS dan Kolam AT disajikan pada Tabel 1.

Berdasarkan data kualitas air tersebut, bahwa sungai Cikapundung mengindikasikan sebagai sungai yang sudah tercemar organik. Hal tersebut antara lain ditunjukkan oleh tingkat keasaman air sungai yang mengarah ke $\mathrm{pH}$ asam (6.8) dan diperkuat oleh kandungan nitrogen $(\mathrm{N})$ yang konsentrasinya hampir 2,5 kali kandungan $\mathrm{N}$ pada air tanah, juga kandungan karbon organic (C) yang konsentrasinya hamper 50 kali kandungan C pada air tanah.

Tabel 1.Karakteristik Beberapa Parameter Kualitas Air Sungai (AS) Cikapundung dan Air Tanah (AT) pada Kolam AS dan Kolam AT.

\begin{tabular}{cccc}
\hline Parameter & Unit & Air Sungai & Air Tanah \\
pH & - & 7,15 & 6,87 \\
\hline N-kjeldahl & $\mathrm{mg} / \mathrm{L}$ & 1,06 & 2,4 \\
P-posfat & $\mathrm{mg} / \mathrm{L}$ & 0,47 & 0,40 \\
C-organik & $\mathrm{mg} / \mathrm{L}$ & $<0,1$ & 5,03 \\
\hline
\end{tabular}

Tingginya konsentrasi $\mathrm{C}$ dan $\mathrm{N}$ dalam air sungai tersebut, diharapkan mampu dimanfaatkan oleh tanaman makrofit untuk kebutuhan pertumbuhan dan berkemang biak, sekaligus memperbaiki kualitas perairan sungai Cikapundung secara .bertahap

\subsection{Performa Pertumbuhan Fisik}

Uji pemanfaatan tanaman talas (Colocasia esculenta) dalam menurunkan pencemaran organik air sungai Cikapundung dilakukan di bantaran Sungai Cikapundung, Tamansari, dibawah jembatan laying Pasopati, Kota Bandung. Data sementara hasil pengukuran sampel yang tersedia adalah data fisik, seperti panjang akar, tinggitanaman, beratkering tunas, beratkering akar, dimana kesemuanya itu menunjukkan indicator fisik dari tumbuh kembangnya suatu tanaman.

Data hasil penguakuran tersebut disajikan pada Tabel 2, untuk indikasi tanaman talas yang tumbuh pada kolam kajian yang dialiri air sungai Cikapundung. Sedangkan Tabel 3, adalah data hasil pengukuran dari tanaman talas yang tumbuh pada kolam kajian yang dialiri air sumur / air tanah.

Secara umum, data hasil pengukuran tinggi dan berat kering tunas serta panjang dan berat kering akar, menunjukkan adanya perbedaan pertumbuhan, dengan selisih panjang $(\mathrm{cm})$ dan selisih berat (grm) dari tinggi tunas, panjang akar, berat kering tunas dan berat kering akar talas yang tumbuh pada kolam kajian air sungai cikapundung, lebih baik dibandingkan dengan pertumbuhan pada kolam kajian yang diberikan air sumur.

Tabel 2. Rerata Pertumbuhan Talas pada Kolam Kajian diberi Air Sungai Cikapundung

\begin{tabular}{|c|c|c|c|c|}
\hline Hari ke- & $\begin{array}{c}\text { Panjang tunas }(\mathrm{cm}) \\
(\mathrm{PT})\end{array}$ & $\begin{array}{c}\text { Panjang akar }(\mathrm{cm}) \\
\text { (PA) }\end{array}$ & $\begin{array}{c}\text { BK tunas (gram) } \\
\text { (BKT) }\end{array}$ & $\begin{array}{c}\text { BK akar (gram) } \\
\text { (BKA) }\end{array}$ \\
\hline 0 & 75,17 & 26,17 & 3,80 & 4,42 \\
\hline 21 & 75,33 & 22,33 & 2,67 & 6,30 \\
\hline 41 & 55,00 & 29,00 & 4,07 & 6,40 \\
\hline 63 & 48,67 & 26,00 & 7,93 & 6,53 \\
\hline
\end{tabular}

Perbedaan pertumbuhan talas yang tumbuh pada kolam dengan air sungai Cikapundung, menunjukkan bahwa air sungai tersebut mengandung nutrien tinggi yang dibutuhkan tanaman tersebut untuk tumbuh dan berkembang. Sebaliknya pada kolam kajian yang diberi air sumur, diduga hanya sedikit mengandung unsur hara yang dibutuhkan oleh tanaman tersebut. Penjelasan lebih lanjut perbedaan tersebut diasjika pada uraian masing masing Gambar grafik dibawah ini.

Tabel 3. Rerata Perumbuhan Talas pada Kolam Kajian diberi Air Sumur.

\begin{tabular}{|c|c|c|c|c|}
\hline Hari Ke- & $\begin{array}{c}\text { Panjangtunas(cm) } \\
(\text { PT) }\end{array}$ & $\begin{array}{c}\text { Panjang gkar (cm) } \\
(\text { PA) }\end{array}$ & $\begin{array}{c}\text { BKtunas(gram) } \\
(B K T)\end{array}$ & $\begin{array}{c}\text { BKakar(gram) } \\
(\text { BKAA) }\end{array}$ \\
\hline 0 & 75,17 & 26,17 & 3,80 & 4,42 \\
\hline 21 & 60,00 & 22,33 & 2,80 & 5,83 \\
\hline 41 & 40,67 & 22,17 & 3,73 & 0,53 \\
\hline 63 & 28,67 & 16,67 & 2,53 & 5,47 \\
\hline
\end{tabular}

Dari Grafik pada Gambar 1 tergambar, bahwa kedua tanaman talas dengan substrat tumbuh berbeda, sama sama mengalami penurunan tinggi tunas, namun secara absolute tunas 
tanaman talas yang tumbuh pada substrat mengandung air sungai Cikapundung (AS) menunjukkan pertumbuhan tinggi tunas lebih baik.

Dari gambaran trend grafik pada Gambar 3, menunjukkan bahwa, tanaman pada kolam air sumur (AT) dan air sunga Cikapundung mampu bertahan / menyesuaikan diri (adaptasi) dengan lingkungannya, sehingga hidup meskipun tidak berkembang.

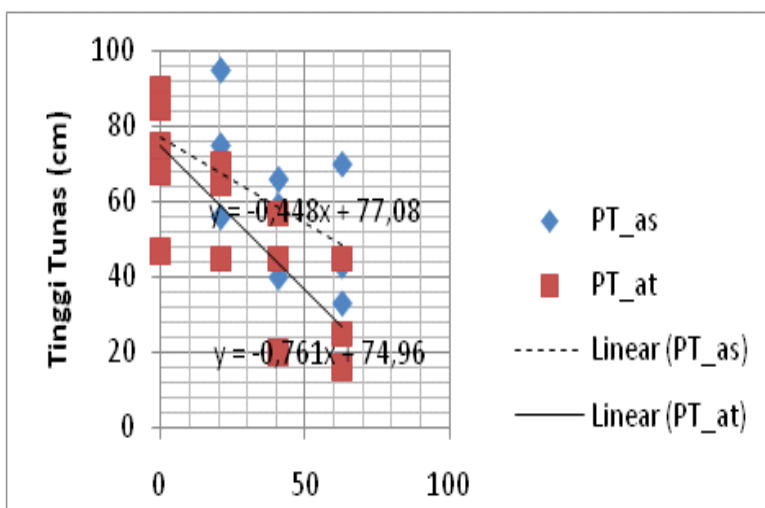

Pengamatan Hari ke:

Gambar 3. Data Hasil Pengukuran Tinggi Tunas Talas pada kolam air sungai Cikapundung (AS) dan kolam air sumur (AT).

Sedangkan dari grafik pertambahan panjang akar, tanaman talas pada kolam AS memiliki akar yang tidak berubah panjangnya, sedangkan tanaman talas yang tumbuh padas kolam AT, Panjangerakarannya semakin susut. Data hasil pengukuran tersebut, disajikan pada Gambar 4 dibawah ini. Grafik tersebut menunjukkan bahwa panjang akar sangat nyata berbeda. Tetapi apakah data yang diperoleh untuk kajian ini sudah cukup dalam menentukan kesimpulan, itupun menjadi bahan pemikiran, mengingat umur tanam baru sekitar 2 bulan.

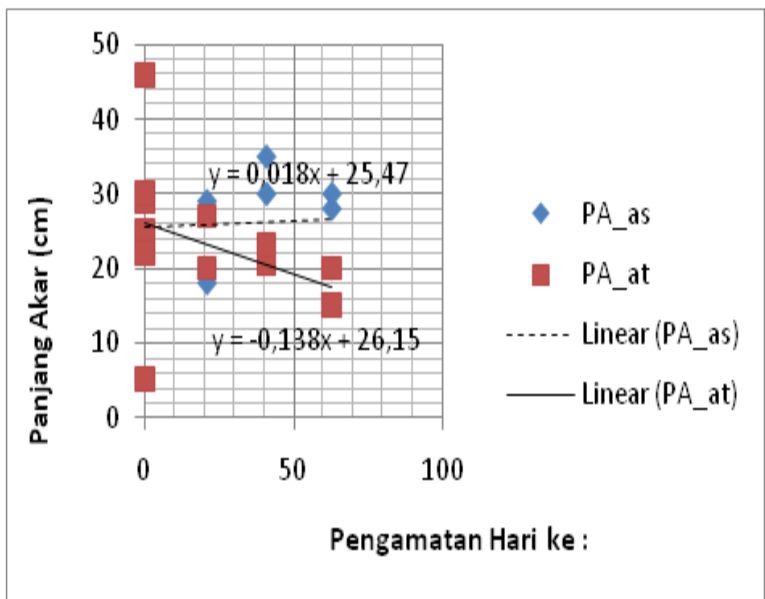

Gambar 4. Data Hasil Pengukuran Panjang Akar Talas pada kolam air sungai Cikapundung (AS) dan kolam air sumur (AT).
Namun dari hasil pengukuran berat kering sampel AS dan sampel AT, menunjukkan bahwa berat kering tunas dan akar pada sampel AS lebih baik dibandingkan dengan hasikl pengukuran BK sampel AT. Dengan demikian untuk melihat pertumbuhan talas pada kolam AS lebih baik dari kolam AT tidak cukup hanya dari pertumbuhan panjang tunas dan akar saja tapi perlu dituinjang oleh penimbangan berak kering, sehingga penarikan kesimpulan menjadi sahih.

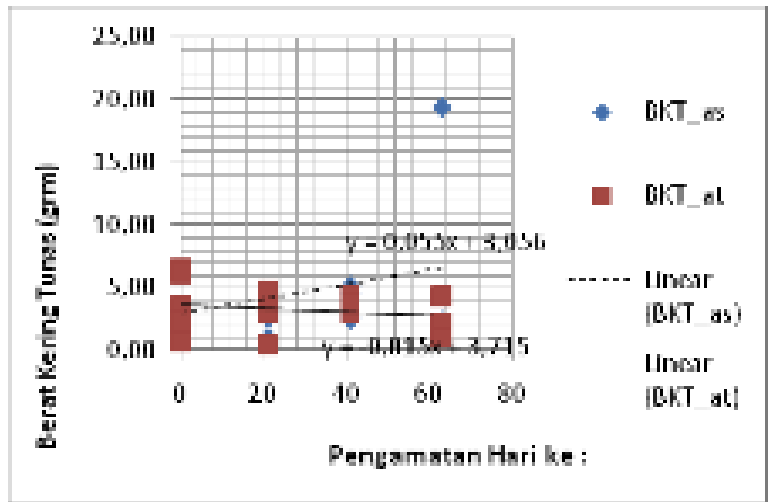

Gambar 5. Data Hasil Pengukuran Berat Kering Tunas pada kolam air sungai Cikapundung (AS) dan kolam air sumur (AT).

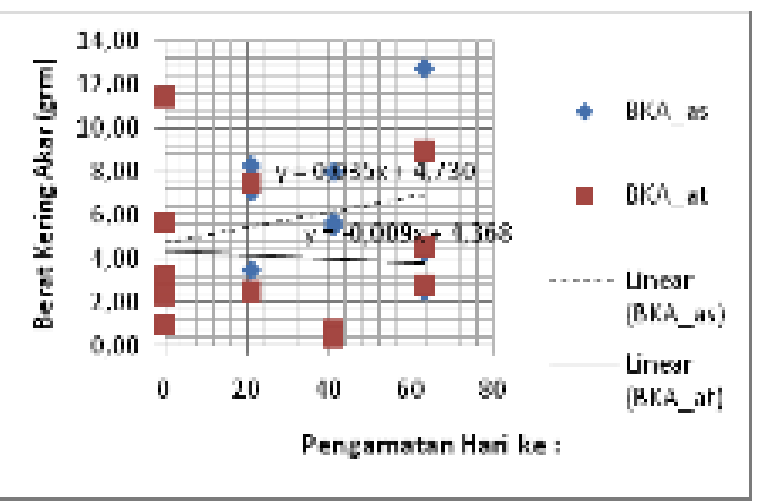

Gambar 6. Data Hasil Pengukuran Berat Kering Akar pada kolam air sungai Cikapundung (AS) dan kolam air sumur (AT).

\subsection{Kemampuan Serap Talas terhadap Nu- trien $(\mathrm{C}, \mathrm{N}$, dan $\mathrm{P})$}

Pemanfaatan tanaman Talas dalam pengolahan limbah domestik dari beberapa literatur menunjukkan hasil yang baik. Tanaman ini mampu mereduksi kandungan pencemar dalam air, terutama nitrogen $(\mathrm{N})$, karbon (C ) dan fosfat $(P)$. Oleh katena itu, pemanfaatan tanaman talas untuk mereduksi pencemaran organik suatu Sungai bisa direkomendasikan, dengan catatan akan mencapai hasil maksimal, bila penetrasi cahaya matahari bekerja maksimal pada kolam treatmen yang dibangun.

Serapan C total oleh tanaman talas, serapan $C$ oleh daun dan serapan $C$ olehbagian akar 
pada Kolam AS lebih tinggi dibandingkan pada Kolam AT sebagaimana ditunjukkan oleh grafik penyerapan C pada Gambar 7 dan Gambar 8. Bahkan kandungan C pada sampel AT menunjukkan penurunan jika dibandingkan dengan kandungan $\mathrm{C}$ talas pada saat awal penanaman di Kolam tersebut. Tingginya serapan C pada perlakuan Kolam AS dan rendahnya bahkan menurunnya kandungan $C$ talas pada kolam AT terkait erat dengan kandungan $\mathrm{C}$ sumber air yang digunakan. Sebagaimana tergambar pada Tabel 1, bahwa kandungan $\mathrm{C}$ air tanah sangat rendah $(<0,1 \mathrm{mg} / \mathrm{L})$ dibandingkan dengan kandungan $\mathrm{C}$ air sungai Cikapundung (5,03 mg/L).

Tabel 4.Rerata Kandungan C Talas (mg) pada Kolam AT dan Kolam AS.

\begin{tabular}{|c|c|c|c|c|}
\hline & \multicolumn{2}{|c|}{ KOLAM AIRTANAH } & \multicolumn{2}{|c|}{ AIR SUNGAI } \\
\hline & 0Hari & GHari & 0 Hari & 63 Hari \\
\hline nמנס & $1.243,031$ & 866,400 & $1.243,081$ & 2792,533 \\
\hline$A_{t r}$ & $15 \pi, 536$ & 356,42 & $15 \%, 536$ & 2084,133 \\
\hline Tolt & 2819,566 & $1.222,80$ & 2819,566 & 4876,667 \\
\hline
\end{tabular}

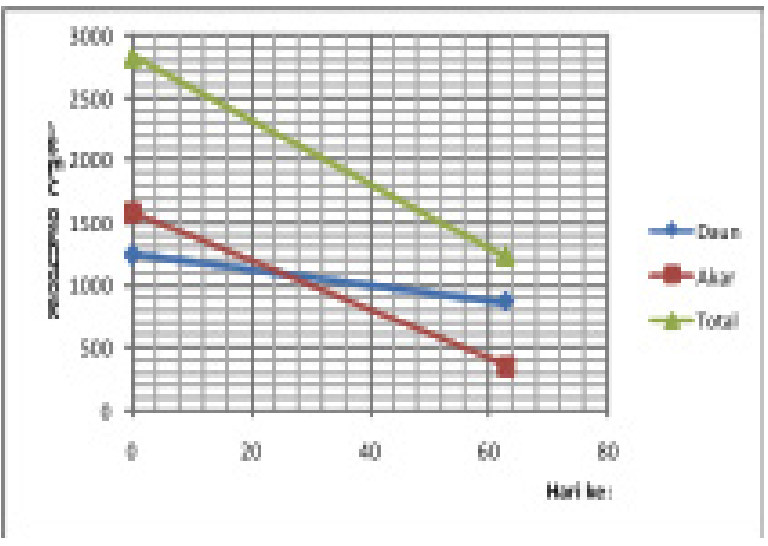

Gambar 7. Serapan Karbon (C) Tanaman Talas Pada Kolam Air Tanah

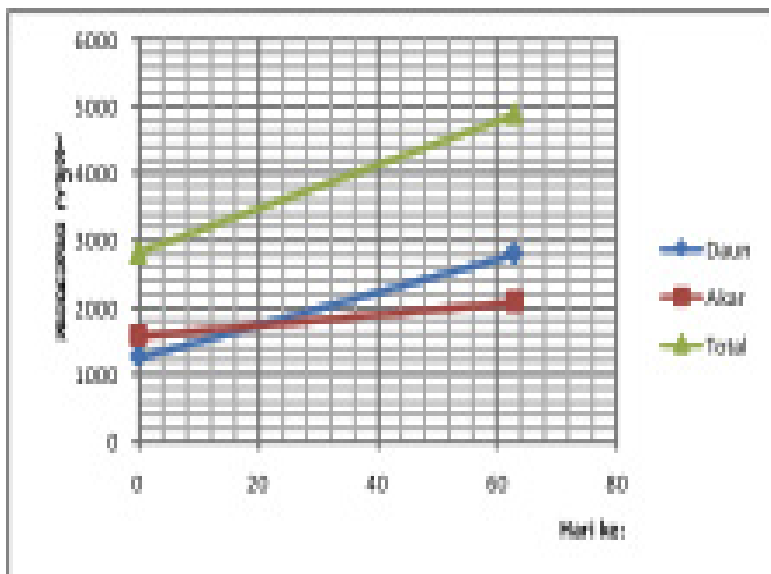

Gambar 8. Serapan Karbon (C) Tanaman Talas Pada Kolam Air Sungai
Dari data pengukuran kadar C jaringan tanaman talas menunjukkan bahwa satu pohon talas yang pada awal kajian mengandung C sebesar 2819,57 grm, untuk tanaman talas Kolam AS pada hari ke 63 menjadi 4876,67 grm, sebaliknya tanaman talas Kolam AT pada hari ke 63 hanya 1222,83 grm (Tabel 4)

Hasil pengukuran kandungan $\mathrm{N}$ jaringan pada tanaman talas, menunjukkan bahwa serapan $\mathrm{N}$ total oleh tanaman talas, serapan $\mathrm{N}$ oleh daun dan serapan $\mathrm{N}$ oleh bagian akar pada Kolam AS lebih tinggi dibandingkan pada Kolam AT sebagaimana ditunjukkan oleh grafik penyerapan N pada Gambar 9 dan Gambar 10.

Bahkan kandungan $\mathrm{N}$ pada sampel AT menunjukkan penurunan jika dibandingkan dengan kandungan $\mathrm{N}$ talas pada saat awal penanaman di Kolam tersebut. Tingginya serapan $\mathrm{N}$ pada perlakuan Kolam AS dan rendahnya bahkan menurunnya kandungan $\mathrm{N}$ talas pada kolam AT terkait erat dengan kandungan $\mathrm{N}$ sumber air yang digunakan. Sebagaimana tergambar pada Tabel 1, bahwa kandungan $\mathrm{N}$ air tanah lebih rendah $(<1,06 \mathrm{mg} / \mathrm{L})$ dibandingkan dengan kandungan $\mathrm{N}$ air sungai Cikapundung $(2,4 \mathrm{mg} / \mathrm{L})$.

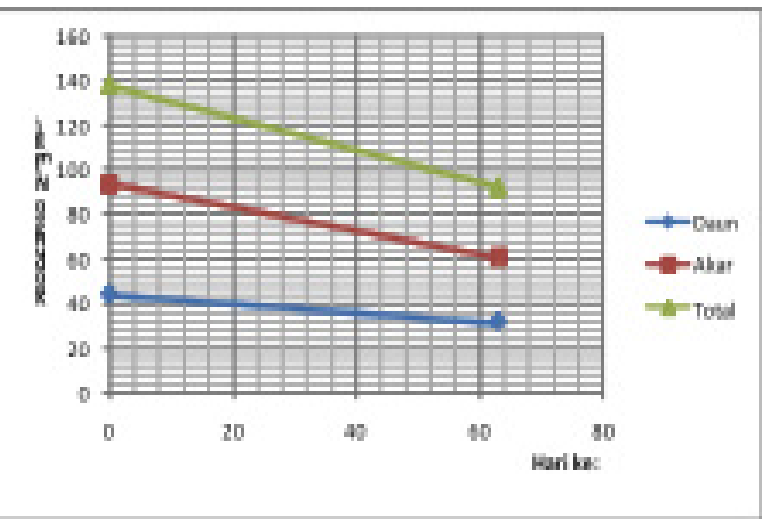

Gambar 9. Serapan Nitrogen (N) Tanaman Talas Pada Kolam Air Tanah

Selanjutnya menurut data pengukuran kadar $\mathrm{N}$ jaringan tanaman talas menunjukkan bahwa satu pohon talas yang pada awal kajian mengandung $\mathrm{N}$ sebesar $44,10 \mathrm{grm}$, sebaliknya pada pada hari ke 63 , talas di Kolam AS menjadi 240,61 grm, sebaliknya tanaman talas Kolam AT pada hari ke 63 hanya 92,10 grm (Tabel 5)

Tabel 5. Rerata Kandungan N Talas (mg) pada Kolam AT dan Kolam AS.

\begin{tabular}{|c|c|c|c|c|}
\hline & \multicolumn{2}{|c|}{ KOAM AR TAMH } & \multicolumn{2}{|c|}{ AR SUNGAN } \\
\hline & 0 Hari & 63 Hari & 0 Hari & 63 Hari \\
\hline Datn & 44,095 & 31,413 & 44,095 & 126,933 \\
\hline Akar & 93,621 & 60,680 & 93,621 & 113,600 \\
\hline Total & 137,716 & 92,093 & 137,716 & 240,613 \\
\hline
\end{tabular}




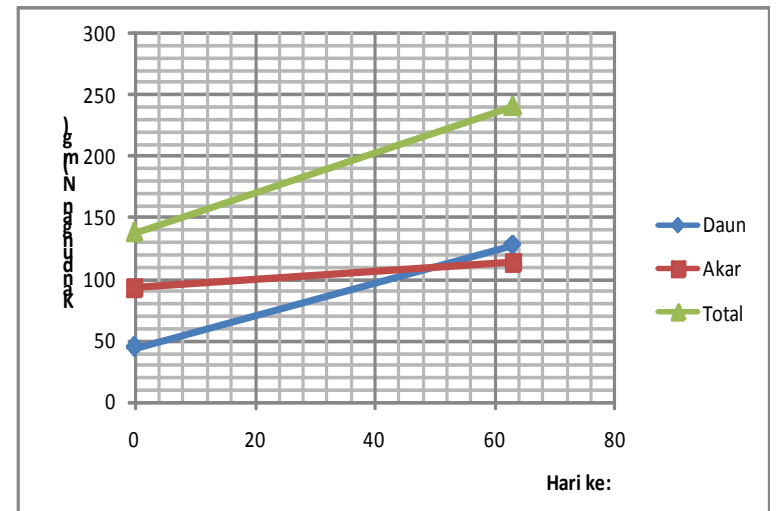

Gambar 10. Serapan Nitrogen (N) Tanaman Talas Pada Kolam Air Sungai.

Untuk hasil pengukuran total serapan $P$ oleh jaringan tanaman talas pada Kolam AS dan Kolam AT, menunjukkan serapan yang tidak jauh perbedaannya, pada awal kajian (6,64 mg.L) dan akhir kajian untuk Kolam AS $6,58 \mathrm{mg} / \mathrm{L}$ dan Kolam AT $5,85 \mathrm{mg} / \mathrm{L}$.

Sedangkan serapan $\mathrm{P}$ total oleh daun talas, Kolam AS menunjukkan konsentrasi yang berbeda dimana pada awal kajian 2,66 mg/L menjadi $3,7 \mathrm{mg} / \mathrm{L}$ pada akhir kajian; sebaliknya untuk Kolam AT menunjukkan konsentrasi yang menurun pada akhir kajian $(2.03 \mathrm{mg} / \mathrm{L}$

Sebaliknya serapan dibagian akar, terjadi penurunan pada akhir kajian baik pada Kolam AT maupun Kolam AS, sebagaimana disajikan pada Tabel 6, Gambar 11 dan Gambar 12.

Tabel 6. Rerata Kandungan P Talas (mg) pada Kolam AT dan Kolam AS.

\begin{tabular}{|l|r|r|r|r|}
\hline \multirow{2}{*}{} & \multicolumn{2}{|c|}{ KOLAM AIR TANAH } & \multicolumn{2}{c|}{ AIR SUNGAI } \\
\cline { 2 - 5 } & \multicolumn{1}{c|}{ 0 Hari } & \multicolumn{1}{|c|}{63 Hari } & \multicolumn{1}{c|}{ 0 Hari } & \multicolumn{1}{c|}{63 Hari } \\
\hline Daun & 2,661 & 2,027 & 2,661 & 3,967 \\
\hline Akar & 3,974 & 3,827 & 3,974 & 2,613 \\
\hline Total & 6,635 & 5,853 & 6,635 & 6,580 \\
\hline
\end{tabular}

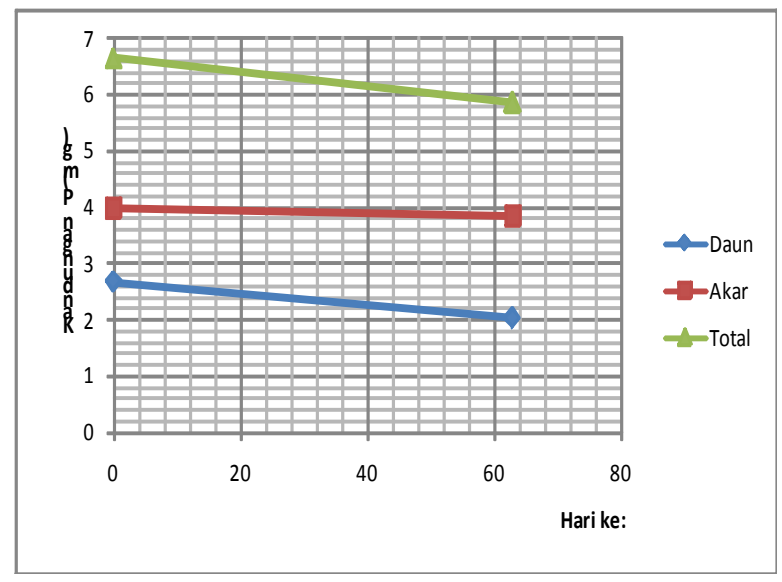

Gambar 11. Serapan Posfor (P) Tanaman Talas Pada Kolam Air Tanah
Rendahnya serapan $\mathrm{P}$ baik pada kolam AS maupun Kolam AT, diperkirakan terkait erat dengan rendahnya kadar $\mathrm{P}$ pada kedua sumber air yang digunakan (air tanah dan air sungai Cikapundung), sebagaimana tergambar pada hasil analisa Laboratorium terhadap kandungan $\mathrm{P}$ air tanah dan air sungai pada Tabel 1.

Namun demikian, rendahnya kandungan $P$ dalam air tanah dan air sungai bukan merupakan kendala bagi laju pertumbuhan tanaman secara umum, karena memang tanaman hanya memerlukan sangat kecil konsentrasinya dalam pembentukan sel.

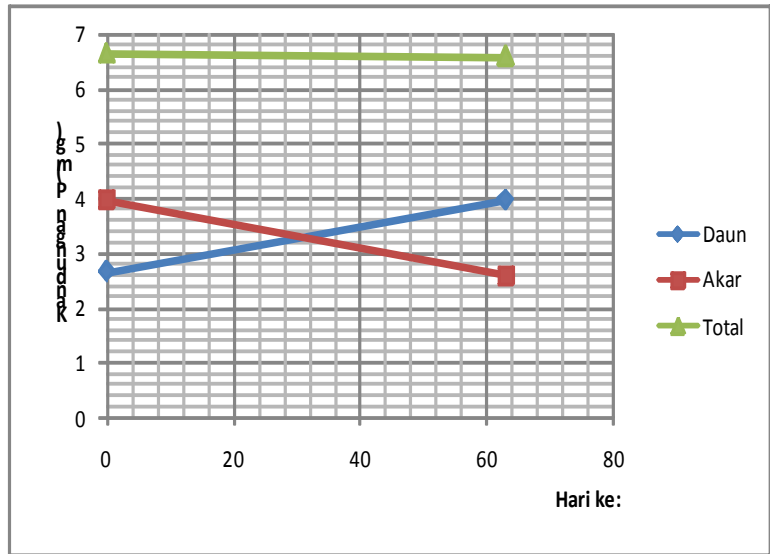

Gambar 12. Serapan Posfor (P) Tanaman Talas Pada Kolam Air Sungai

\section{KESIMPULAN}

Uji coba pemanfaatan tanaman talas dalam fitoremediasi air sungai dapat dimanfaatkan, mengingat hasil yang dicapai sudah memperlihatkan kemampuannya tanaman talas dalam menyerap bahan pencemar organik sungai Cikapundung yang digunakan untuk pertumbuhan, Pertumbuhan talas pada Kolam AS lebih baik dibandingkan dengan pertumbuhan di Kolam AT, diduga terkait dengan pasokan nutrien pada Kolam AT yang rendah, sedangkanKolam AS tinggi karena limbah organik yang masuk kedalam sungai Cikapundung. Penyerapan bahan organic (C,N dan P) oleh tanaman talas mencapai 2000 mguntuk $\mathrm{C}$ dan $100 \mathrm{mg}$ untuk $\mathrm{N}$ selama 63 hari. Perlu dilakukan uji lanjutan untuk mengetahui pada umur berapa, tanaman tersebut sudah maksimal menyerap bahan organic, sehingga perlu dilakukan penyegaran atau perlu dipanen.

\section{DAFTAR PUSTAKA}

1. Kansiime, F., H. Orvem-Origa and S. Rukwago. 2005. Comparative assessment of the value of papyrus and cocoyams for the restoration of the Nakivubo wetland in Kampala, Uganda. Physics and Chemistry of the Earth 30 : 698-705.

2. Bindu, T., V.P. Sylas, M. Mahesh, P.S. Rakesh, E.V. Ramasamy. 2008. Pollutant removal from domestic 
wastewater with Taro (Colocasia esculenta) planted in a subsurface flow system. Ecological engineering $33: 68-82$.

3. Bindu T and Ramasamy E.V. Phytoremediation Of Domestic Wastewater With Colocasia Esculenta. School Of Environmental Sciences, Mahatma Gandhi University, Kottayam, Kerala-686008. http ://210.212.24.72/ kscsteuser/digital-library/digital/ KSC/ksc19/08-Ecology\%20\&\%20Environment/ 08-General/08-38.pdf

4. Annonymous. 1997.Constructed Wetlands for Animal Waste Treatment. Alabama Soil and Water Conversation Committee (ASWCC) and National Councel of Pulp and Paper Industry for Air and Stream Improvement (NCASI). USA.

5. Wijetunga S., D.H.U. Sandamali and K.D.N. Weerasinghe. 2009. Evaluation Of Efficacy In The Treatment Of Domestic Wastwater By Different Aquatic Macrophytes. Journal of Environmental Research And Development Vol. 4 No. 2, :297-309.

6. Geeganage K. T., A. J. Mohotti, M. Ariyarathne, K.M. Mohotti and R.L.R. Chandrajith. 2011.
Phytoremediation of Metal Polluted Soils by Ipomoeaaquatica and Colocasia Esculenta. Proceedings of the Peradeniya University Research Sessions, Sri Lanka, Vol. 16, 24: 134-

7. Parmar Pritesh, Mandakini Patel, Bhaumik Dave and R.B. Subramanian. 2012. Identification of Colocassia esculentum a Novel Plant Spp for the Application of Phytoremediation. African Journal of Basic \& Applied Sciences 4 (3): 67-72, 2012.

8. Brown V. M., and H. Asemota. 2009. X. Campestris pv. dieffenbachiae, the Causative Agent of Common Leaf Blight Disease in Dasheen (Colocasia sp.) and Cocoyam (Xanthosoma sp.). Journal of Biotech Research [ISSN: 1944-3285] 2009; 1:1-12.

9. Adelekan, B. A. 2012. An Evaluation of the Global Potential of Cocoyam (Colocasia and Xanthosoma species) as An Energy Crop. British Journal of Applied Science \& Technology 2(1): 1-15.

10. Goenaga R. 1995. Accumulation and Partitioning of Dry Matter in taro (Colocasia esculenta (L.) Schitt). Annals of Botany 76:337-341. 
